\title{
An Investigation on the Audit Committees Effectiveness: The Case for GLCs in Malaysia
}

\author{
Nurul Nazlia Jamil \\ Kuliyyah of Economics and Management Sciences, International Islamic University Malaysia \\ Sherliza Puat Nelson \\ Kuliyyah of Economics and Management Sciences, International Islamic University Malaysia
}

\begin{abstract}
Financial reporting quality has been under scrutiny especially after the collapse of major companies. The main objective of this study is to investigate the audit committee's effectiveness on the financial reporting quality among the Malaysian GLCs following the transformation program. In particular, the study examined the impact of audit committee characteristics (independence, size, frequency of meeting and financial expertise) on earnings management in periods prior to and following the transformation program (2003-2009). As of 31 December 2010, there were 33 public-listed companies categorized as Government-Linked Companies (GLC Transformation Policy, 2010) and there were 20 firms that have complete data that resulted in the total number of firm-year observations to 120 for six years (years 2003-2009). Results show that the magnitude of earnings management as proxy of financial reporting quality is influenced by the audit committee independence. Agency theory was applied to explain audit committee, as a monitoring mechanism as well as reducing agency costs via gaining competitive advantage in knowledge, skills, and expertise towards financial reporting quality. The study is important as it provides additional knowledge about the impact of audit committees effectiveness on reducing the earnings management, and assist practitioners, policymakers and regulators such as Malaysian Institute of Accountants, Securities Commission and government to determine ways to enhance audit committees effectiveness and improve the financial reporting of GLCs, as well as improving the quality of the accounting profession.
\end{abstract}

Abstrak: Kualitas pelaporan keuangan telah di bawah pengawasan, terutama setelah runtuhnya perusahaan-
perusahaan besar. Tujuan utama dari penelitian ini adalah untuk mengetahui efektivitas komite audit pada
kualitas pelaporan keuangan antara GLCs Malaysia yang mengikuti program transformasi. Secara khusus,
studi ini meneliti dampak dari karakteristik komite audit (kebebasan, ukuran, frekuensi pertemuan dan
keahlian keuangan) pada manajemen laba pada periode sebelum dan setelah program transformasi (2003-
2009). Pada tanggal 31 Desember 2010, ada 33 perusahaan publik yang terdaftar berkategori sebagai link
Pemerintah-Perusahaan-perusahaan (GLC Transformation Policy 2010) dan ada 20 perusahaan berdata lengkap
sehingga jumlah perusahaan di tahun pengamatan mencapai 120 perusahaan selama enam tahun (tahun
2003-2009). Dari hasil penelitian menunjukkan bahwa besarnya manajemen laba sebagai proksi dari kualitas

Corresponding author. E-mail: nurul.nazlia@gmail.com 
pelaporan keuangan dipengaruhi oleh independensi komite audit. Teori keagenan diaplikasikan untuk menjelaskan komite audit, sebagai mekanisme pemantauan serta mengurangi biaya agensi melalui keunggulan kompetitif dalam pengetahuan, keterampilan, dan keahlian terhadap kualitas pelaporan keuangan yang diperolehnya. Penelitian ini penting karena memberikan pengetahuan tambahan tentang dampak efektivitas komite audit dalam mengurangi manajemen laba, dan membantu praktisi, pembuat kebijakan dan regulator seperti Institut Akuntan Malaysia, Komisi Efek dan pemerintah untuk menentukan cara untuk meningkatkan efektivitas komite audit dan meningkatkan pelaporan keuangan GLCs, serta meningkatkan kualitas profesi akuntansi.

Keywords: audit committees; earnings management; GLCs transformation program; Malaysia 


\section{Introduction}

Audit committee effectiveness has become prevalent in the uprising corporate governance agenda around the globe, and also in emerging economies. Malaysia is no exceptional. Malaysian Code of Corporate Governance (MCCG) and Bursa Listing Requirement were introduced as the best practices to improve the corporate governance among Malaysian listed companies. Furthermore, the progress of corporate governance in Malaysia was strengthened when the government introduced the Green Book through their GLC's transformation program* in the year 2004. The comprehensive guidelines in the 'Green Book on Enhancing Board Effectiveness' was distributed to all GLCs by 31st December 2005 and they were required to follow these guidelines by 1 st January 2007 (GLC Transformation Manual 2005). The Green Book's objective is to provide manual guidelines to raise the overall effectiveness of the boards that are consistent with MCCG, Bursa's Listing Requirements and other legislations.

Prior literatures such as DeZoort et al. (2002), Klein (2002), Felo et al. (2003), Xie et al. (2003) and Abbott et al. (2004), demonstrate that effective audit committees ensure better monitoring of the management in ensuring a good financial reporting quality. Additionally, until now various studies have been conducted regarding the relationship between audit committee effectiveness and financial reporting quality of publicly listed companies, but few focusing on the GLCs. GLCs are known as key drivers of the Malaysian economy and come with their own characteristics. To date, four percent or 20 GLCs in Bursa Malaysia's GLCs are able to generate RM 235.5 billion (49 percent) of total market capitalization of the Malaysian economy, and directly contribute about ten per cent to the Malaysia Gross Domestic Product. These figures proved that the GLCs as a group are one of the contributors towards the growth of country.

Thus, it is very important for GLCs to maintain their effectiveness to sustain their contribution to the Malaysian economic growth. In addition, in Malaysia there is a limited number of evidence in measuring the effectiveness of audit committees through the financial reporting quality among GLCs companies. Hence motivates the current study and significantly assists the government in evaluating improvement of the existing policy. This is important to safeguard investors and public interest as principal stakeholders against the misbehavior of managers, and thus increases investor and public confidence in the Malaysian GLCs. Therefore, in light of this situation, the current study seeks to investigate the ability of the audit committee to enhance board effectiveness on the financial reporting quality which subsequently provides recent evidence on Malaysian GLCs.

\footnotetext{
*Note: 1. GLCs Transformation Program is to transform the Government to be more effective in its delivery of services and accountable for outcomes that matter most to the public and second, to move Malaysia forward to become an advanced, united, and just society with high standards of living for all.

2. Khazanah Nasional Berhad (KNB) is the investment holding arm of the Government of Malaysia. It manages the assets held by the Government and undertakes new investments.

3. Employee Provided Fund (EPF) is mandated to provide retirement benefits to its members through the efficient and reliable management of their savings.
} 
In particular, the study examines the impact of audit committee characteristics (independence, size, frequency of meeting and financial expertise) on earnings management in a period prior to and following the GLCs Transformation Program (2003-2009). GLC Transformation is the program that improves performance of Government-linked companies. The government's efforts at improving performance in companies under its control or stewardship will have a positive demonstrative effect on the rest of the corporate sector. Undertaking such a program should result in a sustainable lift to the current trajectory of GLC performance, improving Malaysia's ability to achieve its mission in economic growth. In the current study, the transformation program is expected to have improved the audit committee's effectiveness where the audit committee is one of the components to improve the GLCs' performances. Based on the aforementioned research objective, the following research question (RQ) is yet to be answered:

RQ: What is the impact of audit committee's effectiveness on the financial reporting quality among Malaysian GLCs subsequent to the Transformation program?

This paper is organized as follows, the second section will give a brief literature review that will then be followed by theoretical framework, hypotheses and methodology. The next section will be the analysis of results and discussion. The last section will provide the conclusion with brief explanation on the limitations and suggestions for future research.

\section{Literature Review}

GLCs are peculiar economic entities as they may have public policy objectives even though they operate as corporate organizations (Mazzolini 1979; Powell 1987). They engage in a vast range of activities in diverse fields and can be fully owned or partially owned by the Government. According to Putrajaya Committee GLC (PCG) high performance, (2007) GLCs are defined as companies that have a primary commercial objective and in which the Malaysian Government has a direct controlling stake through Khazanah, Ministry of Finance (MOF), Kumpulan Wang Amanah Pencen (KWAP), and Bank Negara Malaysia (BNM). The GLCs are also controlled by other federal government linked agencies such as Permodalan Nasional Berhad (PNB), Employees Provident Fund (EPF) and Tabung Haji. Apart from a percentage of ownership, controlling stake also refers to the government's ability to appoint board members, senior management and make major decisions (e.g. award contracts, strategy, restructuring and financing, acquisitions and divestments etc.) for GLCs either directly or through Government Link Investment Companies (Hamid 2011).

GLCs were established as a solution to accelerate economic and social developments. Governments created GLCs in order to control certain key sectors considered vital for the development of the national economy (Razak et al. 2011). GLCs are controlled by the Malaysian government via the Federal Government-Linked Investment Companies (GLICs). GLICs are investment arms of the government that allocate government funds to the GLCs and they are vital in the Malaysian economy. To complement the MCCG 2000, the Putrajaya Committee on Government Link Companies (GLC) High Performance (PCG) introduced a framework to guide GLC transformation and upgrade the effectiveness of GLC Boards with the introduction of the 'Green Book'. The study is 
motivated from the empirical result by Hamid (2011) who concluded that GLCs are relatively more transparent in corporate governance practices and this adds to their higher valuations. Thus, the effectiveness of the audit committee is the main subject in the current study to examine whether the best practice adopted will bring in value to GLCs through its financial reporting quality.

For GLCs in Malaysia, the measure of adequacy of these mechanisms is how effective the guidelines provided in the Green Book are on enhancing audit committee's effectiveness with the quality of financial reporting. To improve the financial reporting quality of the GLCs, transformation program they are equipped with the Green Book manual to provide guidelines in enhancing board effectiveness. The guidelines are significant as the benchmark because the study will provides recent evidence on the audit committee's effectiveness after the transformation program as recommended by the PCG's guideline. Thus, it will further contribute to the debate on the firm's control mechanism. The current study seeks specifically on the audit committee's effectiveness because audit committees play a role not only as monitoring devices but other responsibilities are also included such as appointing external auditors and determination of audit fees, review of the quarterly and year-end financial statements of the board and reviewing the firm's internal control (MCCG 2007). The study investigates whether the independence of audit committees, the size of audit committees, the frequency of meetings and financial expertise of the audit committees in GLC companies affect the quality of financial reporting. The findings will be significant because they will enable government authorities to assess the effectiveness of the transformation program and thus take appropriate ac- tions. The study extends the literature by using pre and post transformation programs so as to study the impact of the effectiveness of the audit committees on the GLC's financial reporting quality following the GLCs transformation program.

\section{Theoretical Framework and Hyphotheses Development}

In the current study, agency theory (AT) is found to be relevant to the study, because it explains the audit committee, which functions as a monitoring mechanism to reduce agency costs (Menon and Williams 1994). According to agency theory, separation between the owner and manager, which results in the separation between ownership and control, subsequently leads to agency costs. In order to mitigate the agency costs, contracts are written between the parties that Jensen and Meckling (1976) named the agency relationship. In relation to the existing study, the board of directors represents the agent, and the shareholders are the principals. Whilst, the audit committee, as part of the board of directors, is viewed as a monitoring device and used to prevent opportunistic behavior and strengthen the quality of financial reporting, so as to mitigate agency conflicts between preparers of financial statements and outside shareholders (Piot 2004).

In this study, the audit committees are expected to play a significant role as the monitoring device and intended to strengthen corporate governance functions which indirectly will likely improve the financial reporting quality (Sivaramakrishnan and Yu 2008). To improve the financial reporting quality of GLCs, the transformation program is equipped with the Green Book manual to provide guidelines in enhancing board effec- 
tiveness. A specific part of the Green Book contains audit committee charters for the GLCs to adhere to and functions as the recommendations made for improving audit committee effectiveness. Four of their recommendations are; (i) a majority of audit committees should be independent directors, (ii) audit committees should comprise of at least three members, (iii) at least one of the Directors must be a Malaysian Institute of Accountants (MIA) member or have three years working experience and (iv) audit committees should meet at least once a year. With these requirements, they are able to understand and interpret financial statements to effectively fulfill their role in monitoring the company's system of internal control and financial reporting. Thus, the hypotheses will be developed based on the audit committee characteristics, which include its independence, size, frequency of meeting and financial expertise.

\section{Audit Committee Independence}

The role of an audit committee is to safeguard an organization through its authority to question top management regarding the way financial reporting responsibilities are handled, as well as to make sure that corrective actions are taken. Thus, for GLCs in $\mathrm{Ma}$ laysia, the Green Book stipulates that all GLCs companies must have audit committees comprising of three members of whose majority shall be independent. The committee oversees the reporting process as well as the internal control mechanism within an organization.

As in the case of the board of directors, the monitoring function on behalf of shareholders is enhanced as the independence of the committee increases. Prior research suggests that financial statement frauds are more likely to occur in firms with less audit committee independence (Bronson et al. 2009). Audit committee independence helps to ensure quality audits and contributes to financial statement user reliance on the financial reporting process. In relation to the role of audit committees on the quality of financial reporting, Beasley et al. (1999) finds that independent audit committees significantly reduce the likelihood of financial misstatement. Thus, this relationship suggests independent audit committee members are effective to control earnings management practices. Hence, the first hypothesis is:

$H_{1}$ : Firms with a higher number of independent audit committee members are negatively related to the magnitude of earnings management.

\section{Audit Committee Size}

As mentioned earlier, the Green Book recommended in the audit charter section that GLC companies need to appoint the audit committee amongst its directors that are to be composed of not fewer than three members. A larger audit committee may result in potential problems in the financial reporting process being uncovered and resolved. This might be due to the fact that as the size of an $\mathrm{AC}$ increases there will be more resources available within the committee, hence improving the quality of oversight. Dalton et al. (1999) found a positive relation between size and the monitoring function of the board that results in higher performance documented in prior studies.

The MCCG is consistent with the Listing Requirement of Bursa Malaysia that audit committees shall comprise of at least three directors. However, there is a question of whether larger audit committee size would lead to more effective monitoring. It is expected that the larger committee size increases the resources available to the audit 
committee and improves the quality of oversight, which meant reducing the level of earnings management. It is assumed that with more members, more diverse skills and knowledge are employed by the committee to enhance monitoring, hence improving the quality of the financial reporting. Thus, the hypothesis is conjectured as follows:

$\mathrm{H}_{2}$ : Firms with a higher number of audit committee members are negatively related to the magnitude of earnings management.

\section{Audit Committee Meeting}

The audit committee, which intends to play a major role in oversight, would need to maintain a high level of activity. The audit committee requires meetings at least once a year as recommended by the Green Book. The audit committee should meet regularly, with due notice of issues to be discussed and should record its conclusions in discharging its duties and responsibilities. The frequency of audit meetings is assumed to increase the effectiveness of monitoring (Collier and Gregory 1999). In addition, Zhang et al. (2007) argue that the effectiveness of audit committees might increase the numbers of meeting when there are significant problems in control, consistent with Abbott et al. (2002). Therefore, it is expected that the more often an audit committee meets; the more active it is being perceived and leads to fewer financial reporting problems (Menon and William 1994). Hence, the third hypothesis is:

\section{$H_{3}$ : Firms with higher frequency of audit committee meetings are negatively related to the magnitude of earnings management.}

\section{Audit Committee Expertise}

Audit committees are responsible for numerous duties that require a high degree of accounting sophistication such as, understanding auditing issues and risks as well as the audit procedures proposed to address them and evaluating judgmental accounting areas. Thus, consistent with the recommendations in the Green Book, audit committees in GLCs must have least one Director who is a Malaysian Institute of Accountants (MIA) member or have three years working experience. To be effective in performing their role in oversight of the financial reporting quality, the audit committee should be composed of people with some financial expertise (Bedard et al. 2004).

The audit committees need to evaluate financial reporting quality as part of its oversight responsibilities. Therefore the members are required to be financially literate and at least one of them should be a financial expert, as there is a need to assess and evaluate financial reporting. As noted by Baxter and Cotter (2009), firms with higher earnings quality have a greater proportion of qualified accountants on audit committee. Further, as documented by Nelson (2011), audit committee experts contribute to the financial reporting quality; when it was shown that accounting affiliates audit committees have negative and significant relationship with discretionary accruals. Hence the fourth hypothesis is conjecture as follows:

$H_{4}$ : Firms with higher proportion of audit committee with financial expertise are negatively related to the magnitude of earnings management. 


\section{Research Design}

\section{Sample}

This study utilized secondary data as the main source of information. The information relating to the audit committee independence, size, frequency of meeting, expertise, firm size, leverage and return on asset (ROA) are collected from company annual reports. As of 31 December 2010, there were 33 public listed companies categorized as Government Linked Companies (GLC Transformation Policy 2010). These GLCs were classified into six major industries including trading and services, plantation, finance, construction, consumer product, industrial product, infrastructure project companies (IPC), and technologies.

The availability of data for these 33 GLCs was examined to ensure the abnormal accrual in each industry from year 2003 to 2009. In addition, these accounting data is important to ensure each sector-year contained more than 10 observations. The data covered from the period of pre until the period of post transformation as to fulfill the discretionary accrual estimation requirements and to see the impact of transformation on

Table 1. Sample Selection the magnitude of management earning activities. For analysis comparison of the transformation program, the study denotes the period of 2003 to 2005, as the pre-transformation program, and 2007 to 2009, as the post transformation program. It is also acknowledged that the effect of the transformation program could be seen for a few years after the issuance of the circular. Year 2006 is eliminated to account for the transformation transition period.

The final sample is 20 companies from 33 GLCs, as shown in Table 1. The total firmyear observations become 120 for six years (years 2003-2009). The companies selected are from four major sectors which are comprised of 12 companies from trading and services sector, three companies from consumer product, three from industrial product and one each from the plantation and construction sector respectively. The GLCs from IPC and technologies sectors are excluded in the final sample due to less than 10 observations from each sector-year and non-availability of data. GLCs in the finance sector are not selected because of their financial statement's components that are difference from non-finance sectors.

Companies

Listed GLC as at 31 December 2009 (total population)

(less) incomplete data

(less) companies from finance industry

(less) companies from IPC

Total Sample 
Data was collected from Datastream database and hand-collected from the annual report of each GLC company for six years from year 2003 to year 2009. Annual reports are downloaded from Bursa Malaysia's website and the company's main portal. Content analysis technique was used to extract the data from the corporate governance statement and some data is in the financial statement. The time period of six years was selected in this study because this study's aim is to examine the impact of audit committees effectiveness on the financial reporting quality in Malaysian GLCs following the transformation program.

\section{Research Method}

The study adopts a two-step research process. First step is in measuring the discretionary accruals, which is the proxy of earnings management. Second step is pooled regression analysis to test the association between the dependent variable (DACC) and the independent variables of audit committee characteristics (AC independent, $\mathrm{AC}$ size, AC frequency of meeting and AC expertise).

Measuring Discretionary Accruals (DACC) as proxy of Financial Reporting Quality. Financial reporting quality is represented by the magnitude of earnings management. The discretionary accrual (DACC) is becoming a proxy of earnings management. Klein (2002b), Yang and Krishnan (2005) and Rahman and Ali (2006) had implemented the level of accruals as a proxy for their financial reporting quality. To measure discretionary accruals, this study applies the Dechow and Dichev (2002) accrual quality model, which has recently been considered as a better proxy for earnings quality (Jaggi et al. 2007). The
Dechow and Dichev (2002) model is measured by estimating the following regression (all variables are scaled by average assets):

$$
\begin{aligned}
\Delta \mathrm{TCAjt}= & \alpha 0 \mathrm{j}+\alpha 1 \mathrm{jCFOjt}-1+ \\
& \alpha 2 \mathrm{jCFOjt}+\alpha 3 \mathrm{jCFOjt}+1+ \\
& \text { vt..............(1) }
\end{aligned}
$$

$\Delta \mathrm{CAjt}=\quad$ Firm $j \mathrm{~s}$ total current accruals in year $t,(\Delta \mathrm{CAjt}-\Delta \mathrm{CLjt}$ - $\Delta$ Cashjt $+\Delta$ STDEBTjt

$\Delta \mathrm{CAjt}=\quad$ Firm $j \mathrm{~s}$ change in current assets between year $t-1$ and year $t$,

$\Delta \mathrm{CLjt}=\quad$ Firm $j \mathrm{~s}$ change in current liabilities between year $t-1$ and year $t$,

$\Delta$ Cashjt $=\quad$ Firm $j$ s change in cash between year $t-1$ and year $t$,

$\triangle \mathrm{STDEBTjt}=$ Firm $j \mathrm{~s}$ change in debt in current liabilities between year $t-1$ and year $t$,

Assetsjt $=\quad$ Firm $j$ s average total assets in year $t$ and $t-1$; and

$\mathrm{CFOjt}=\quad$ Firm $j$ s net cash flow from operation in year $t$.

Pooled Regression Analysis. The study attempts to investigate the impact of audit committees effectiveness on the financial reporting quality in Malaysian GLCs following the transformation program. An audit committee's effectiveness is modeled as independent variables and other control variables consistent with prior studies. The definition and measurement of variables is in Table 2. The discretionary accruals (DACC) model is as follows: 
$\mathrm{DACC}=\beta_{1}$ ACCINDEP $+\beta_{2}$ ACCSIZE $+\beta_{3}$ ACCMEET $+\beta_{4}$ ACCEXPERT +

$$
\beta_{5} \mathrm{SIZE}+\beta_{6} \text { LEVERAGE }+\beta_{7} \mathrm{ROA}+\varepsilon
$$

Table 2. Definition of Variables

\section{Variables}

\section{Dependent Variable}

Discretionary accruals (DACC)

\section{Independent Variables}

Audit committee independent (ACINDEP)

Audit Committee Size (ACSIZE)

Audit Committee Meetings (ACMEET)

Audit Committee Expert (ACEXPERT)
Total accrual minus non discretionary accrual.

The proportion of audit committee being independent

Total number of audit committee members

The number of audit committee meeting held during the financial year

The proportion of audit committee members possess professional accounting qualifications (ACCA etc) or member of any professional accounting bodies (MIA,CPA etc) to total number of audit committee members

Firm size in natural log.

The ratio of total liabilities to total assets.

The ratio of net income to total assets. 


\section{Analysis of Design and Discussions}

\section{Descriptive Analysis}

Table 3 presents the descriptive statistics of all variables investigated in this study. The table shows the mean, standard deviation, minimum and maximum values of the dependent and independent variables. Using data from 120 observations of annual reports for the periods of pre and post transformation programs (2003-2009), it is found that the average of earnings management for the sample is 0.003 . It is consistent with previous studies that show a positive mean such as Dechow et al. (1995) that reports a mean of 0.002. On the other hand, the current study shows an interesting result when the current discretionary accruals are lowered; as compared to other Malaysian studies by Rahman and Ali (2006) that reports a mean of 0.0132, Atef (2009) at 0.1652, and Nelson (2011) of 0.0604. Subsequently, suggesting more effectiveness of the guidelines on financial reporting quality of GLCs, and better quality of financial reporting as compared to other Malaysia companies.

\section{Correlation Analysis}

Table 4 shows that absolute DACC are significantly negatively correlated with firm

Table 3. Descriptive Statistics $(\mathbf{N}=\mathbf{1 2 0})$

\begin{tabular}{lcccc}
\hline \multicolumn{1}{c}{ Variables } & Minimum & Maximum & Mean & Std. Deviation \\
\hline ABSOLUTE DACC & 0.000 & 0.455 & 0.003 & 0.001 \\
ACINDEP & 0.20 & 1.00 & 0.701 & 0.750 \\
ACSIZE & 3 & 9 & 4.34 & 0.983 \\
ACMTG & 3 & 21 & 5.98 & 2.724 \\
ACEXPERT & 0.125 & 1.00 & 0.297 & 0.139 \\
SIZE (LOG 10) & 8 & 10.6 & 9.379 & 0.570 \\
LEVERAGE & 0.0004 & 0.910 & 0.401 & 0.235 \\
ROA -0.412 & 0.659 & 0.065 & 0.137 & \\
\hline Note $:$ DACC $=$ & Total accrual minus non discretionary accruals; & & \\
ACINDEP $=$ & The proportion of audit committee being independence. & \\
ACSIZE $=$ & Number of AC member; & & \\
ACMEET $=$ & The number of audit committee meetings held during the financial year; \\
ACEXPERT $=$ & The proportion of audit committee members possess professional accounting qualifications \\
(ACCA etc) or member of any professional accounting bodies (MIA,CPA etc) to total number & \\
of audit committee members; & \\
SIZE $=$ & Firm size in natural log; \\
LEV $=$ & The ratio of total liabilities to total assets and \\
ROA $=$ & The ratio of net income & \\
& &
\end{tabular}


Jamile̋ Nelson

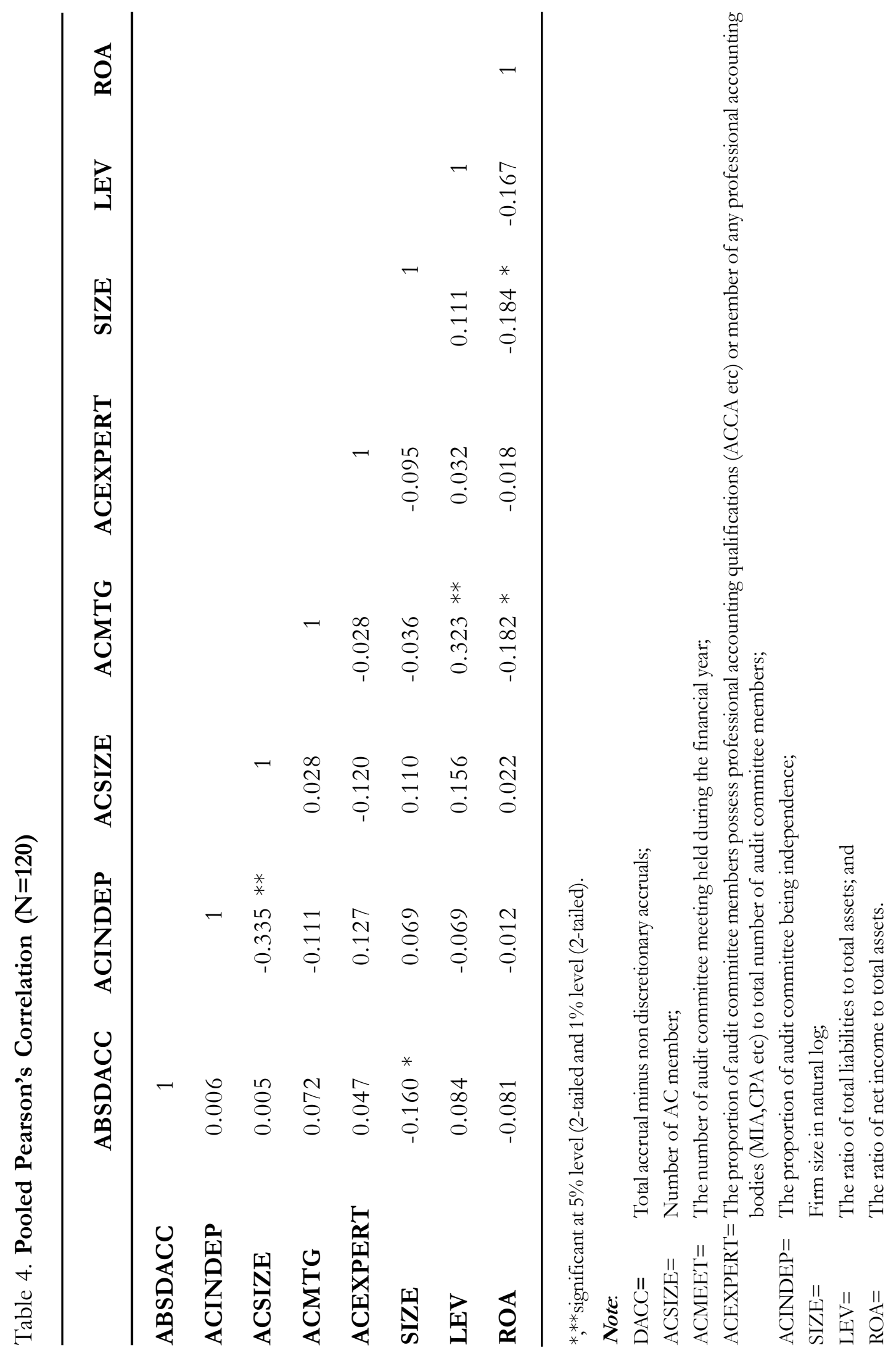


size and ROA. Other independent variables and control variables are not correlated with the absolute DACC. The highest correlation is between ACINDEP and ACSIZE, 0.335, which suggests that multicollinearity is not a serious problem since none of the variables were found to exceed 0.9 (Tabachnick and Fidell 2007), while, absolute DACC are positively correlated with audit committee independence, size, expertise, frequency of meeting and leverage. Many prior studies in earnings management literature document a negative association of firm's size with earnings management such as Gul et al. (2002), Klein (2002b), Krishnan (2003) and Balsam et al. (2003).

\section{Pooled Regression Analysis}

Table 5 summarizes the regression analysis results for the pooled data of transformation program (2003-2009). The F-value for the pooled data for pre and post transformation programs is statistically significant at the 1 percent level where the p-value is 0.069 . The $R^{2}$ is 12.3 percent and the adjusted $R^{2}$ for the pooled data is 6.9 percent. The adjusted $R^{2}$ is consistent with Hashim and Susela (2008b) who examined the relationship board independence, CEO duality and accrual management with adjusted $R^{2}, 9.1$ percent. One possible reason for low adjusted $\mathrm{R}^{2}$ for pooled periods is the small number of GLCs companies that were available before and after transformation program. This is consistent with prior studies by Yen et al. (2007) utilizing only 25 samples of GLCs., Razak et al. (2008) at 27 GLCs over the period 1995 to 2005 to examine the impact of GLCs ownership structure and corporate per- formance, and recently, Najid and Rahman (2011) at 47 GLCs for a period from 2001 to 2006.

Hypothesis $1\left(\mathrm{H}_{1}\right)$ proposed that the audit committees with more independent members are negatively related with the magnitude of earnings management. The result of the study from the pooled data found a negative and significant relationship between DACC and AC independence. The result is consistent with Klein (2002) that shows there is a negative relationship between independent audit committees and earnings management. This relationship suggests independent audit committee members are effective in controlling earnings management practices. Thus, $H_{1}$ is supported.

Audit committee size (ACSIZE) shows a positive non-significant relationship hence; H2 that expect a negative relationship with the magnitude of earnings management is not supported. The result contradicts with prior studies such as Yang and Krishnan (2005), and Lin et al. (2006) where audit committee size had a negative association with earnings management. For ACMEET and ACEXPERT, the results show a positive direction and are not significant. Similar to previous Malaysian studies such as Rahman and Ali (2006) and Ismail et al. (2008), there is no evidence to indicate that audit committee meetings and expertise significantly impact financial reporting quality. Besides, the findings of this study are not consistent with prior studies such as Xie et al. (2003), Bedard et al. (2004) and Park and Shin (2004), which found that lower earnings management is associated with the presence of a financial expert in the audit committee. In a nutshell, $H_{3}$ and $H_{4}$ are not supported. 
Table 5. Pooled Regression Analysis

DACC $=\beta_{1}$ ACCINDEP $+\beta_{2}$ ACCSIZE $+\beta_{3}$ ACCMEET $+\beta_{4}$ ACCEXPERT $+\beta_{5}$ SIZE $+\beta_{6}$ LEVERAGE $+\beta_{7}$ ROA $+\varepsilon$

\begin{tabular}{|c|c|c|c|c|c|}
\hline & & Coefficients & $\begin{array}{c}\text { Standard } \\
\text { Error }\end{array}$ & $\begin{array}{c}\text { Significant } \\
\text { (t-stat) }\end{array}$ & p-value \\
\hline \multirow{5}{*}{$\begin{array}{l}\text { Independent } \\
\text { Variables }\end{array}$} & (constant) & 0.170 & 0.095 & 1.681 & 0.096 \\
\hline & ACINDEP & -0.007 & 0.041 & -0.172 & $0.003 * *$ \\
\hline & ACSIZE & 0.001 & 0.016 & 0.186 & 0.153 \\
\hline & ACMTG & 0.100 & 0.012 & -0.040 & 0.268 \\
\hline & ACEXPERT & 0.008 & 0.039 & 0.204 & 0.238 \\
\hline \multirow{13}{*}{$\begin{array}{l}\text { Control } \\
\text { Variables }\end{array}$} & FIRMSIZE & -0.018 & 0.010 & -1.932 & 0.056 \\
\hline & LEVERAGE & 0.021 & 0.025 & 0.854 & 0.395 \\
\hline & ROA & -0.036 & 0.041 & -0.889 & 0.376 \\
\hline & DUMMY YEAR 2003 & 0.027 & 0.019 & 1.416 & 0.160 \\
\hline & DUMMY YEAR 2004 & -0.008 & 0.019 & -0.424 & 0.673 \\
\hline & DUMMY YEAR 2005 & -0.010 & 0.018 & -0.538 & 0.591 \\
\hline & DUMMY YEAR 2007 & 0.017 & 0.018 & 0.933 & 0.353 \\
\hline & DUMMY YEAR 2008 & 0.046 & 0.018 & 2.540 & 0.013 \\
\hline & $\mathrm{N}$ & 120 & & & \\
\hline & $\mathrm{R}^{2}$ & 0.123 & & & \\
\hline & Adjusted $\mathrm{R}^{2}$ & 0.069 & & & \\
\hline & F-value & 1.737 & & & \\
\hline & P-value & 0.069 & & & \\
\hline
\end{tabular}

*,**significant at $5 \%$ level (2-tailed and $1 \%$ level (2-tailed).

Note: $\mathrm{DACC}=$ Total accrual minus non discretionary accruals;

ACINDEP $=$ The proportion of audit committee being independent.

ACSIZE $=\quad$ Number of $\mathrm{AC}$ member;

ACMEET $=$ The number of audit committee meetings held during the financial year;

ACEXPERT $=$ The proportion of audit committee members possessing professional accounting qualifications (ACCA etc) or member of any professional accounting bodies (MIA, CPA etc) to total number of audit committee members;

SIZE $=\quad$ Firm size in natural log;

$\mathrm{LEV}=\quad$ The ratio of total liabilities to total assets; and

$\mathrm{ROA}=\quad$ The ratio of net income to total assets. 


\section{Conclusion}

This study examines the impact of audit committee's effectiveness on the financial reporting quality in Malaysian GLCs following to the transformation program. The study was motivated by the emphasis given by the Malaysian government. The effort by the government has contributed to good corporate governance practices on the financial reporting quality of Malaysian GLCs through the GLCs' transformation program. Financial reporting quality is being proxied by earnings management. Earnings management can be measured by persistence, predictability, smoothness, discretionary accruals and accrual quality model. To measure earnings management, this study employed the accrual quality model developed in Dechow and Dichev (2002) as a better proxy for earnings quality (Francis et al. 2004; Doyle et al. 2007; Jaggi et al. 2007). To see the impact of the audit committee effectiveness such as AC independence, AC size, AC financial expertise, $\mathrm{AC}$ frequency of meeting and discretionary accruals as the proxy of earnings management, a total of 120 non-financial GLC companies listed on Bursa Malaysia's Main Board, over the period of 2003-2009, with complete data for discretionary accruals and audit committee characteristics as the measure of board effectiveness were selected.

On the other hand, the study was not able to find any association with the magnitude of earnings management on the audit committee size, audit committee expertise, frequency of meeting, FIRMSIZE, LEVERAGE and ROA except for audit committee independence. Hypothesis $1\left(\mathrm{H}_{1}\right)$ proposed that the audit committees with independent members are negatively related with the magnitude of earnings management. The result of the study from the regression analysis found a negative and significant relationship between DACC and AC independence. The main evidence shows that the presence of independent audit committees possibly reduces earnings management practices thus leading to higher financial reporting quality. This finding is consistent with suggestions from prior studies (Abbott and Parker 2000, and Carcello and Neal 2000) indicating independent audit committees enhance corporate governance.

Audit committee size (ACSIZE) and frequency of meeting (ACMEET) show positive direction for the study. It contradicts with the hypothesis $\left(\mathrm{H}_{2}\right)$ and $\left(\mathrm{H}_{3}\right)$ where a negative relationship is expected with the magnitude of earnings management. Thus, the result contradicts with prior studies such as Yang and Krishnan (2005), and Lin et al. (2006) where audit committee size has a negative association with earnings management. The findings are consistent with Rahman and Ali (2006) and Ismail et al. (2008); there is no evidence to indicate that audit committee frequency of meeting and expertise significantly impact financial reporting quality. Furthermore, the findings of this study are not consistent with prior studies such as Xie et al. (2003), Bedard et al. (2004) and Park and Shin (2004) that found lower earnings management are associated with the presence of a financial expert among the members of the audit committee. Xie et al. (2003) argue that boards that meet more often could reduce earnings management activity as they are able to allocate more time for issues such as earnings management, while boards that seldom meet are unlikely to focus on these issues.

In addition, AC financial expertise (ACEXPERT) is found to be non- significant because the study focuses on AC members who are qualified accountants. For example, in a Korean study, Choi et al. (2007) the fo- 
cus is on the different professional backgrounds of directors to investigate the effects of a director's quality on firm performance. They examine different professional backgrounds of outside directors such as lawyers, accountants, bankers, politicians, government officials, and academicians as well as executives of affiliated and non-affiliated firms. Their results show a positive contribution of executives of non-affiliated firms and academicians to firm performance. Perhaps, investigation on the different professional backgrounds of AC members will provide an interesting avenue for future research.

In a nutshell, it appears that only audit committee independence influences the audit committee's effectiveness on the quality of reporting in GLCs following the transformation program. This study provides investors, regulators, and other financial information users with an understanding of the role audit committee independence have on the occurrence of earnings management activities in GLCs. The results found in this study may serve as an input for the regulator to encourage a 100 percent audit committee independence from the management. Besides, there are problems that can be addressed such as, based on several initiatives in improving corporate governance in Malaysian GLCs like MCCG 2000 (revised 2007) and transformation program, Malaysian GLCs generally have lower performance as compared to their rival private sector firms. Although an important aim of the transformation is to make
GLCs top performing companies, this requires them to adopt a profit orientated corporate culture rather than retaining their bureaucratic practices. In addition, some GLCs are unable to meet their profit targets because of their parallel needs to address social concerns. This could also be attributable to the weak management structures and possibly undue political interference in the decisionmaking processes. All in all, these problems possibly need to be concerned in ensuring the corporate governance initiatives for GLCs in Malaysia can achieved their objectives.

There are some limitations that can be highlighted in this study. First, this study is limited to 120 Malaysian GLCs from various sectors listed in Bursa Malaysia due to the availability of data. The number of GLCs companies in Malaysia is relatively low; hence leaves no choice to utilize the whole population. Secondly, this study cannot be generalized to other countries (particularly developed countries) with different regulated market and high investor protection, less family ownership, high reliance on public debt, less concentrated and no pyramidal ownerships, because GLCs in Malaysia maybe have been defined differently from other companies in other parts of the world. In addition, this issue is prevalent in developing countries where financial statement users are less likely to be able to see through the manipulated earnings, partly due to the financial statements, which are less transparent, and less sophisticated users. 


\section{References}

Abbott, L. J., and S. Parker. 2000. Audit committee characteristics and auditor choice. Auditing: A Journal of Practice and Theory 19 (2): 47-66.

Abbott, L. J., S. Parker, and G. F. Peter. 2004. Audit committee characteristics and restatements. Auditing: A Journal of Practice and Theory 23 (1): 69-87.

Atef, M. Y. 2009. Does audit committee constraint discretionary accruals in MESDAQ listed companies? International Journal of Business and Social Science 1 (3).

Balsam, S., J. Krishnan, and J. S. Yang. 2003. Auditor industry specialiszation and earnings quality. Auditing: A Journal of Practice and Theory 22 (2) (September): 71.

Baxter, P., and J. Cotter. 2009. Audit committees and earnings quality. Accounting and Finance 49: 267-290.

Beasley, M.S. 1996. An empirical analysis of the relation between the board of director composition and financial statement fraud. The Accounting Review 71 (4): 443-465.

Beasley, M. S., J. V. Carcello, and D. R. Hermanson. 1999. Fraudulent Financial Reporting: 1987-1997 An Analysis of US Public Companies. New York, NY: COSO

Bedard, J., S. M. Chotourou, and L. Corteau. 2004. The effect of audit committee expertise, independence, and activity of aggressive earnings management. Auditing: A Journal of Practice and Theory 23 (2): 13-35.

Bronson, S. N., J. V. Carcello, C. W. Hollingsworth, and T. L. Neal. 2009. Are fully independent audit committee necessary? Journal of Accounting and Public Policy 28: 265-280.

Carcello, J.V., and T. L. Neal. 2000. Audit committee composition and auditor reporting. The Accounting Review 75 (4): 453-467.

Cohen, D. A., A. Dey and T. Z. Lys. 2008. Real and accrual-based earnings management in the pre- and post-Sarbanes-Oxley period. The Accounting Review 83 (3): 757-787.

Collier, P., and A. Gregory. 1999. Audit committee activity and agency costs. Journal of Accounting and Public Policy 18: 311-332.

Choi, J. J, S. W. Park, and S. S. Yoo. 2007. The value of outside directors: Evidence from corporate governance reform in Korea. Journal of Financial and Quantitative Analysis 42 (4). 941-962.

Dalton, D. R., and C. M. Daily. 1999. No return on independence, chief executive. Strategic Management Journal 138: 58-59.

Dechow, P. M., R. G. Sloan, and A. P. Sweeney. 1995. Detecting earnings management. The Accounting Review 70 (2): 193-225.

Dechow, P. M., and I. D. Dichev. 2002. The quality of accruals and earnings: The role of accrual estimation errors. The Accounting Review 77 (Supplement): 35-59.

DeZoort, F. T., D. R. Hermanson, D. S. Archambeault, and S. Reed. 2002. Audit committee effectiveness: A synthesis of the empirical audit committee literature. Journal of Accounting Literature 21: 38-75.

Dowdell, T. D. and J. Krishnan. 2004. Former audit firm personnel as CFOs: Effect on earnings management. Canadian Accounting Perspectives 3 (1): 117-142.

Doyle, J. T., W. Ge, and S. McVay. 2007. Accruals quality and internal control over financial reporting. The Accounting Review 82 (5): 1141-1170.

Felo A. J., S. Krishnamurthy, and S. A. Solieri. 2003. Audit committee characteristics and the perceived 
quality of financial reporting: an empirical analysis. Working Paper. Graduate School of Professional Studies, Penn State University, Great Valley, Malvern, PA.

Francis, J, R. LaFond, P. M. Olsson, and K. Schipper. 2004. Cost of equity and earnings attributes. The Accounting Review 79 (4): 967-1010.

Gendron, Y., and J. Bedard. 2006. On the constitution of audit committee effectiveness. Accounting, Organisations, and Society 31: 211-239.

Gul, F.A., S. G. Lynn, and J. S. L. Tsui. 2002. Audit quality, management ownership, and the informativeness of accounting earnings. Journal of Accounting, Auditing, and Finance 17 (1): 25-49.

Hamid, A. A. 2011. Network Governance in Government linked companies and Non-government linked companies in Malaysia. Journal of Financial Reporting and Accounting 9 (1): 54-73.

Hashim, H. A., and D. Susela. 2008b. Board independence, CEO duality and accrual management. Asian Journal of Business and Accounting 1 (1): 27-46.

Ismail, H., T. M. Iskandar, and M. Rahmat. 2008. Corporate reporting quality, audit committee and quality of audit. Malaysian Accounting Review 7 (1).

Jaggi, B., and S. Leung. 2007. Impact of family dominance on monitoring of earnings management by audit committee: Evidence from Hong Kong. Journal of International Accounting, Auditing and Taxation 16: 27-50.

Jensen, M., and W. Meckling. 1976. Theory of the firm: Managerial behavior, agency costs and ownership structure. Journal of Finance and Economics, Vol. 3, pp. 305-360.

Klein, A. 2002. Audit committee, board of director characteristics, and earnings management, Journal of Accounting and Economics 33: 375-400.

Klein, A. 2002a. Economic determinants of audit committee independence. The Accounting Review 77 (2): 435-452.

Klein, A. 2002b. Audit committee, board of director's Characteristics and earnings Management. Journal of Accounting and Economics 33: 375-400.

Krishnan, G. V. 2003. Does big 6 auditor industry expertise constrain earnings management? Accounting Horizons, Vol. 17, (Supplement), pp. 1-16.

Lin, J. W., J. F. Li, and J. S. Yang. 2006. The effect of audit committee performance on earnings quality. Managerial Auditing Journal, 21(9), 921-933.

Mac 2007. Putrajaya Committee GLCs High Performance's Summary of Transformation Manual.

Mak, Y. T., and C. K. Chng. 2000. Corporate governance practices and disclosures in Singapore: An update. International Research Journal of Finance and Economics 61: 35-59.

Malaysian Code on Corporate Governance. 2007. Finance Committee on Corporate Governance, Securities Commission. Kuala Lumpur.

Mazzolini, R. 1979. Government Controlled Enterprises: International Strategic and Policy Decisions. John Wiley \& Sons.

Menon, K., and D. Williams. 1994. The use of audit committees for monitoring. Journal of Accounting and Public Policy 13: 121-139.

Najid, N. A., and R. Rahman. 2011. Government ownership and performance of Malaysian Government-Linked Companies. International Research Journal of Finance and Economics 61: 35-59. 
Nelson, S. P. 2011. Audit Committee Expertise and Financial reporting quality: An Empirical Study in Malaysia. LAP Lambert Academic Publishing: Germany.

Park, Y. W., and H. H. Shin. 2004. Board composition and earnings management in Canada. Journal of Corporate Finance 10: 431-457.

Persons, O. S. 2005. The relation between the new corporate governance rules and the likelihood of financial statement fraud. Review of Accounting \& Finance 4 (2): 125-148.

Piot, C., and R. Janin. 2004. External auditors, audit committee and earnings management in France. European Accounting Review 16 (2): 429-254.

Powell, V. 1987. Improving Public Enterprise Performance: Concepts and Techniques. Geneva: International Labour Office.

The STAR. 2010. Transforming the GLCs (12 $2^{\text {th }}$ June).

Qin, B. 2007. The Influence of audit committee financial expertise on earnings quality: US evidence. ICFAI Journal of Audit Practice 4 (3): 7-28.

Rahman, R. A., and F. H. Ali. 2006. Board, audit committee, culture and earnings management: Malaysian evidence. Managerial Auditing Journal 21 (7): 783-804.

Razak, N. H., and R. Ahmad, H. J. Aliahmed. 2008. Ownership structure and corporate performance" A comparative analysis of government Linked and Non-government linked companies from Bursa Malaysia. Corporate Ownership and Control 6 (2) (Winter): 434-442.

Razak, N. H., R. Ahmad, and H. J. Aliahmed. 2011. Does government linked companies perform better than Non Government Linked Companies: Evidence in Malaysia. Journal of Applied Finance and Banking. (1) (1): 213-240.

Saleh, N. M., T. M. Iskandar, and M. N. Rahmat. 2007. Audit committee characteristics and earnings management: Evidence from Malaysia. Asian Review of Accounting 15 (2): 147-163.

Sivaramakrishnan, K.; and S. C. Yu. 2008. On the association between corporate governance and earnings quality. Working Paper. University of Hoston.

Tabachnick, B. G., and L. S. Fidell. 2007. Using Multivariate Statistics ( $5^{\text {th }}$ ed.). USA: Pearson Education Inc.

The Green Book. 2006. Enhancing Board Effectiveness. Putrajaya Committee on GLC High Performance, Malaysia.

Xie, B., W. N. Davidson III, and P. J. DaDalt. 2003. Earnings management and corporate governance: The role of the board and the audit committee. Journal of Corporate Finance 9: 295-316.

Yang, J. S., and J. K. Krishnan. 2005. Audit committees and quarterly earnings management. International Journal of Auditing 9: 201-219.

Yen. J. W, L. S. Chun, S. Z. Abidin, and B. A. Noordin. 2007. Earnings management practises between Government Linked Companies and Chinese Linked Companies. International Journal Economics and Management: 387-406.

Zhang, Y., J. Zhou, and N. Zhou. 2007. Audit committee quality, auditor independence, and internal control weaknesses. Journal of Accounting and Public Policy 26: 300. 